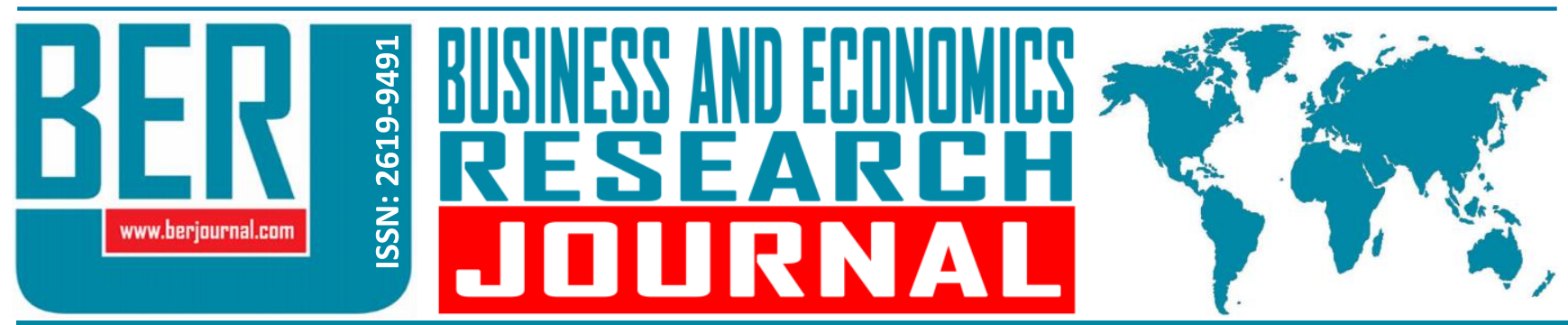

Business and Economics Research Journal Vol. 11, No. 2, 2020, pp. 571-579 doi: 10.20409/berj.2020.268

\section{Zorunlu Vatandaşlık Davranışı Ölçeğinin Türkçeye Uyarlanması: Geçerlik ve Güvenirlik Çalışması}

\author{
Lutfi Surucu $^{\mathrm{a}}$, Ahmet Maslakci ${ }^{\mathrm{b}}$, Harun Sesen
}

Öz: Araştırmanın amacı, Vigado-Gadot (2007) tarafından geliştirilen zorunlu vatandaşlık davranışı ölçeğinin Türkçeye uyarlaması ve çevirisinin yapılmasıdır. Böylelikle ölçeğin Türkçe yazınına kazandırılması amaçlanmaktadır. Bu maksatla Muğla'da faaliyet gösteren beş yıldızlı otel çalışanlarına anket uygulaması yapılmıştır ( $n=287)$. Elde edilen veriler doğrultusunda ölçeğin dilsel eşdeğerlik, yakınsak geçerlilik (benzeşim geçerliliği), yapı geçerliği ve güvenilirliği test edilmiştir. Elde edilen bulgular uyarlama ve çeviri çalışması yapılan zorunlu vatandaşlık davranışı ölçeğinin geçerli ve güvenilir bir ölçme aracı olduğu ve Türkiye'deki araştırmalarda kullanılabileceğini göstermektedir.

\section{Adaptation of Compulsory Citizenship Behavior Scale into Turkish: The Validity and Reliability Study}

Abstract: The aim of the study is to adapt and translate the compulsory citizenship behavior scale developed by Vigado-Gadot (2007) into Turkish. Thus, it is aimed to adapt the scale into Turkish literature. For this purpose, five-star hotel employees in Muğla were surveyed ( $n=287$ ). The linguistic equivalence, convergent validity, construct validity and reliability of the scale were tested according to the obtained data. The findings showed that compulsory citizenship behavior scale, which is translated and adapted to Turkish, is a valid and reliable instrument and it could be used in further researches in Turkey.
Anahtar Sözcükler: Zorunlu Vatandaşlık Davranışı Ölçeği, Uyarlama, Geçerlik,

Güvenirlik

JEL: M12, D23

Geliş : : 13 Ocak 2020

Düzeltme : 11 Mart 2020

Kabul : 17 Mart 2020

Tür : : Araştırma

Keywords: Compulsory Citizenship Behavior Scale, Adaptation, Validity, Reliability

JEL: M12, D23

Received : 13 January 2020

Revised : 11 March 2020

Accepted : 17 March 2020

Type : Research

Cite this article as: Surucu, L., Maslakci, A., \& Sesen, H. (2020). Zorunlu vatandaşlık davranışı ölçeğinin Türkçeye uyarlanması: Geçerlik ve güvenirlik çalışması. Business and Economics Research Journal, 11(2), 571-579.

The current issue and archive of this Journal is available at: www.berjournal.com

PhD., European Leadership University, Faculty of Economics and Administrative Sciences, Gazimagusa, KKTC, lutfi.surucu@elu.edu.tr (ORCID ID: 0000-0002-6286-4184)

b PhD., Cyprus Science University, Faculty of Economics and Administrative Sciences, Girne, KKTC, ahmetmaslaçi@csu.edu.tr (ORCID ID: 0000-0001-6820-4673)

Prof., PhD., European University of Lefke, Faculty of Economics and Administrative Sciences, Lefke, KKTC, hsesen@eul.edu.tr (ORCID ID: 0000-0002-7068-2487) 


\section{Giriş}

Örgütsel vatandaşlık davranışı (ÖVD), 1980'lerden itibaren birçok araştırmacının ilgisini çekmiştir. Bu ilginin temelinde örgütsel vatandaşlık davranışının örgütlere sağladığı önemli faydalar yatmaktadır. Bu kapsamda yapılan araştırmalar, örgütsel vatandaşlık davranışının; örgütlerin kar marjını yükselttiği (Yen ve Niehoff, 2004), rekabet gücünü artırdığı (Podsakoff vd., 1997), çalışanların iş tatmini (Organ vd., 2006) ve bağlııklarını (Ke ve Wei, 2008) artırdığını belgelemektedir. Yapılan bu araştırmalar doğrultusunda örgütsel vatandaşlık davranışının örgütlere sürdürülebilir rekabet avantajı sağladığını söyleyebiliriz. Bu bağlamda günümüzde artan sayıda örgüt, çalışanlarından daha fazla örgütsel vatandaşlık davranışı göstermelerini isteyerek, işletmelerinin büyümesini desteklemelerini beklemektedir.

Smith vd. (1983), örgütsel vatandaşlık davranışını, "resmi ödül sistemi tarafından açıkça tanınmayan, isteğe bağıı olarak yapılan ve örgütün etkin işleyişini teşvik eden bireysel davranışlar" olarak tanımlamaktadır. Yapılan tanım derinlemesine incelendiğinde, örgütsel vatandaşlık davranışının üç önemli özelliği dikkat çekmektedir. Öncelikle örgütsel vatandaşlık davranışı çalışanlar tarafından gönüllü olarak yapılmalı ve örgütün resmi iş planlaması veya iş gereksinimlerinden bağımsız olmalıdır. íkincisi, örgütsel vatandaşık davranışının resmi ödül sistemiyle ilgisi olmamalı veya resmi ödül sistemi tarafından tanınmamalıdır. Son olarak örgütsel vatandaşlık davranışı gayrı resmi aynı zamanda örgüte fayda sağlayan bir davranış olmalıdır. Örgütsel vatandaşlık davranışı gösteren çalışanlar, genellikle görev tanımında belirtilen işlerin ötesinde çalışmaktadırlar. Bununla beraber diğer çalışma arkadaşlarına yardım etmekte, örgütün başarısı için ek sorumluluklar almakta ve örgütünde daha fazla zaman geçirmektedirler.

Örgütsel vatandaşlık davranışına yönelik literatür bu davranış türünün çalışanların kendi isteğiyle örgütüne katkı sağladığını belirtse de, Vigoda-Gadot (2006) bazı örgütsel vatandaşık davranışlarının, çalışanların kendi istekleriyle başlatılmadığı ve çalışanlar tarafından daha az gönüllülükle yapıldığını vurgulayarak, örgütsel vatandaşlık davranışına farklı bir bakış açısı getirmektedir. Gerçekten de günümüzde örgütler, artan rekabet ortamıyla mücadele edebilmek ve sürdürülebilir rekabet avantajı elde etmek için çalışanlarına örgütsel vatandaşlık davranışı gibi ekstra rol davranışlarını artırmaları konusunda baskı uygulamaktadır (Vigoda-Gadot, 2006). Bu ortam içerisinde çalışanlar, sık sık iş tanımlarının içerisinde bulunmayan görevleri yapmak için güçlü bir sosyal veya yönetimsel baskıyla karşı karşıya kalmaktadırlar.

Çalışanların sık sık güçlü sosyal veya yönetsel baskıyla karşı karşıya kalmaları, çalışanlarda stres ya da hayal kırıklığı yaratmaktadır (Akinlotu ve Ertan, 2018). Bununla beraber, çalışanlar işlerinden daha az memnun olmakta ve işe karşı tatminsizlik duygusu yaşayabilmektedirler (Vigoda-Gadot, 2007). VigodaGadot'a (2006) göre, çalışanlar özgecilik, vicdan, centilmenlik, nezaket ve sivil erdemlilikle örgütsel vatandaşık davranışı gösterseler bile dış baskı uygulandığında örgütsel vatandaşlık davranışı gönüllülük anlamlarını yitirmekte ve böylece zorunlu vatandaşlık davranışının oluşum süreci başlamaktadır. Bu durum örgütsel vatandaşlık davranışının sosyal yapısının olumsuz yönünü yansıtmaktadır. Bu değişim sürecine dayanarak, Vigoda-Gadot (2006), örgütsel vatandaşlık davranışının sınıllarını yeniden tanımlamakta ve örgütsel vatandaşlık davranışını; zorunlu olmayan vatandaşlık davranışı ve zorunlu vatandaşlık davranışı (ZVD) olarak ikiye ayırmaktadır.

Vigoda-Gadot'a (2006) göre, zorunlu vatandaşlık davranışları örgüt içindeki çeşitli sosyal veya yönetsel baskılar nedeniyle gerçekleştirilen anlık olmayan zorunlu davranışlardır ve örgütsel vatandaşık davranışı ile karşılaştııılığında, zorunlu vatandaşlık davranışı, "asında kendiliğinden oluşan davranıştan başka bir olgudur". Görüldüğü üzere zorunlu vatandaşık davranışı kavramı, örgütsel vatandaşlık davranışı kavramının yeniden irdelenmesiyle ortaya çıkmıştır ve örgütsel vatandaşlık davranışının daha çok olumsuz yansımalarını incelemektedir.

Örgütsel vatandaşlık davranışı sadece zorunlu yapılan ve gönüllü olmayan davranışları ifade etmekle kalmaz, aynı zamanda çeşitli kişisel çıkar davranışlarını da içerir. Bu konuda Organ (1997), dolaylı olarak gönüllü olmayan ekstra rol davranışının, gönüllü karakteristiğini vurgulayarak belki de örgütsel vatandaşık davranışının bir parçası olduğunu kabul etmektedir. Ayrıca tüm çalışanların "iyi bir asker" olmaya istekli olmadıklarını ve çeşitli çıkarlarla (terfi, ödül beklentisi vb.) örgütsel vatandaşıı davranışı gösterebileceklerini belirtmektedir (Peng ve Zhao, 2012). Temel olarak belirli ödülleri elde etmek veya olumsuz sonuçlardan 
kaçınmak için de çalışanlar zorunlu vatandaşlık davranışı gösterebilmektedirler. Bununla beraber çalışanların işlerini kaybetme korkusu, diğer iş arkadaşlarının gerisinde kalmaktan kaçınmak istemeleri, amir tarafından düşük performans ile değerlendirilme endişesi gibi konular da zorunlu vatandaşlığın nedenleri arasında gösterilebilmektedir.

Sonuç olarak zorunlu vatandaşlık davranışı, örgütsel vatandaşlık davranışının belli bir sınır sürecinde ortaya çıkmakta ve örgütsel vatandaşlık davranışı ile karşılaştırıldığında, aslında her ikisi de bireyin örgüt içerisinde iş sorumluluklarının ötesinde ekstra rol davranışları göstermesini ifade etmektedir. Fakat her ikisinin ifadelerinde ve içeriklerinde büyük farklılıklar vardır. illk olarak, örgütsel vatandaşlık davranışı, çalışanlarının "iyi asker" olduğuna inanma eğiliminde olan davranışlarının gönüllü olması gerektiğini vurgularken, zorunlu vatandaşlık davranışında, çalışanlarının "iyi" olduğuna inanma eğilimi göstermesine rağmen, çalışanların baskı algıları nedeniyle zorunlu olması gerektiğini vurgulamaktadır (Vigoda-Gadot, 2007). Diğer bir fark ise, örgütsel vatandaşlık davranışlarının gayrı resmi, gönüllülük ve fedakârlıkla yapılmasıdır. Örgütsel vatandaşlık davranışıyla ilgili diğer bir varsayım, örgüt çalışanlarının ekstra rol davranışlarının belirli kişilik özelliklerine veya sorumluluk duygusuna dayandığı şeklindedir. Zorunlu vatandaşlık davranışında ise davranışların kendiliğinden değil, faydacı olduğu vurgulanmaktadır. Ayrıca zorunlu vatandaşlık davranışı örgüt üyelerinin "ekstra rol davranışlarının" terfi ve ödül vb. gibi bir amaca ulaşmasına dayanmaktadır. Son olarak örgütsel vatandaşlık davranışlarının resmi ödül ve ceza sistemi tarafından değerlendirilmediği vurgulanmaktadır. Yani, çalışanların bu tür davranışlarda bulunup bulunmadığı zamanlarda örgüt tarafından ödüllendirilmeyecek veya cezalandırılmayacaktır. Zorunlu vatandaşlık davranışında ise bu tür davranışlar gereksiz değildir ve beklenti içermektedir (Peng ve Zhao, 2012). Zorunlu vatandaşlık davranışı çalışanlara sadece manevi itibar kazandırmakla kalmaz, aynı zamanda yönetim tarafından da ödüller sunmaktadır. Yüksek dereceli zorunlu vatandaşlık davranışları amirlerinin olumlu duygularını tetikleyerek çalışanların daha iyi performans değerlendirmeleri elde etmelerini sağlamaktadır. Ayrıca liderin terfi, eğitim ve ödül tahsisi konusundaki karar verme davranışını da etkilemektedir (Peng ve Zhao, 2012). Aksi durumda ise, çalışanlar örgütleri tarafından beklenen zorunlu davranışları yerine getirmediklerinde, görev sırasındaki sosyal pozisyonları ile birlikte örgütteki resmi pozisyonları da tehlikeye girebilmektedir (Vigoda-Gadot, 2007).

Örgütsel vatandaşlık davranışına yönelik araştırmalar örgüt ve çalışanlar üzerinde olumlu etkilerine odaklanırken, zorunlu vatandaşlık davranışına yönelik araştırmalar ise olumsuz etkileri üzerine odaklanmaktadır. Bu etkilerin içerisinde organizasyonun performansını azaltması, çalışanlarda; iş stresini, ayrılma niyetlerini, ihmalkâr davranış ve tükenmişliklerini artırması bulunmaktadır (Zhao vd., 2013).

Teorik temelleri 2006 yılında Vigado-Gadot tarafından oluşturulan "zorunlu vatandaşlık davranışı" kavramı literatürde 2016 yılından itibaren genel kabul görmeye başlamış ve bu konuda yapılan araştırmalar da bu tarihten sonra artı̧̧ göstermeye başlamıştır. "International Journal of Manpower", "Journal of Business Ethics" ve "The Journal of Psychology" gibi yüksek etki (impact) puanına sahip dergilerde 2017 sonrasında zorunlu vatandaşlık davranışına yönelik araştırmalara yer verilmeye başlanmıştır. Türkçe yazındaki araştırmaların önemli bir kısmı da 2016 ve sonrasına aittir. Mevcut bu durum zorunlu vatandaşlık kavramının dünya yazınına paralel olarak Türkçe yazında da ilginin arttığını göstermektedir. Türkçe yazın incelendiğinde zorunlu vatandaşlık davranış ölçeğinin Türkçeye uyarlaması ve çevirisi yapılmadan, iç tutarlılık kat sayısı dikkate alınarak araştırmaların sonuçlandırıldığı görülmektedir.

Sosyal bilimlerde yapılan araştırmalarda kullanılan ölçüm araçları bölgesel ve kültürel farklılıklardan etkilenmektedir. Bu nedenle ölçeğin orijinal dili ve araştırmanın yapıldığı ülkeler arasındaki kültürel farklııklar araştırma sonuçlarında tutarsızlı̆a sebep olurken, araştırmanın da geçerliliğini tehdit edebilir. Ölçeğinin Türkçeye uyarlanması ve çevirinin yapılması, Türk araştırmacı ve bilim insanlarının zorunlu vatandaşık davranışına yönelik araştırmalarının güvenirliliğini ve geçerliliğini daha da artıracağı değerlendirilmektedir. Bununla birlikte örgütlere olumsuz etkileri olan zorunlu vatandaşlık davranışına yönelik araştırmaların uygulayıcılar arasında farkındalık yaratacağı değerlendirilmektedir.

Araştırmada Vigoda-Gadot (2007) tarafından geliştirilen zorunlu vatandaşlık davranışı ölçeğinin Türkçeye uyarlama ve çeviri çalışması yapılarak ölçeğin Türkçe yazına dâhil edilmesi hedeflenmiştir. Bu maksatla ölçeğin; dilsel eşdeğerlik, yakınsak geçerlilik, yapı geçerliği ve güvenirlik testleri yapılmıştır. 


\section{Yöntem}

Zorunlu Vatandaşlık Ölçeği: Teorik temelleri 2006 yılında Vigoda-Gadot tarafından oluşturulan zorunlu vatandaşlık davranışı kavramının ölçeği yine Vigoda-Gadot tarafından 2007 yılında geliştirilmiştir. İsrail'in kuzeyinde faaliyet gösteren 13 okulda çalışan öğretmenlerden elde edilen veriler ( $n=286$ ) doğrultusunda geliştirilen zorunlu vatandaşlık davranışı ölçeği 5 maddeden oluşan tek boyutlu bir ölçektir. Yapılan bu araştırmada Vigoda-Gadot (2007) zorunlu vatandaşlık davranışı ölçeğini 5'li Likert ölçeği uygulamış ve ölçeğin güvenirliğini 0,83 olarak hesaplamıştır.

Araştırmanın Örneklemi: Araştırma Muğla'da faaliyet gösteren beş yıldızlı otel çalışanları üzerinden yapılmıştır. Araştırma kapsamına alınan üç otelin insan kaynakları müdürü ile görüşülerek araştırmanın amacı ve zorunlu vatandaşlık davranışı hakkında bilgiler verilmiştir. Ayrıca çalışmanın bilimsel amaçlarla yapıldığı ve kişisel verilerin kişi ya da kurum ile paylaşılmayacağı konusunda taahhütte bulunulmuştur. İnsan kaynakları yöneticilerinden gerekli izinler alındıktan sonra anket uygulaması için hazırlanan 450 anket çalışanlara gönüllülük esasına göre dağııımıştır. Araştırmanın güvenirliğini en üst düzeye çıkarmak ve ortak yöntem yanlılığı en aza indirmek için kapalı zarfta dağııılan anketler yine kapalı zarflarda teslim alınmıştır. Hazırlanan 450 anketten 310 ankette geri dönüş sağlanmıştır. Geri dönüş oranı \%68'dir. Elde edilen anketler araştırmacılar tarafından incelendiğinde 23 anketin araştırma kapsamına uygun olmadığı değerlendirildiğinden araştırma kapsamına alınmamıştır. Araştırma 287 verileri anket verisi üzerinden tamamlanmıştır. Katılımcıların demografik özellikleri Tablo 1' de sunulmuştur.

Tablo 1. Katılımcıların Demografik Özellikleri

\begin{tabular}{lcc}
\hline & Sayı (n) & Yüzde (\%) \\
\hline Cinsiyet & & \\
Kadın & 152 & 52,97 \\
Erkek & 135 & 47,03 \\
\hline Yaş grubu & & \\
$25>$ & 68 & 23,69 \\
$26-30$ & 131 & 45,64 \\
$31<$ & 88 & 30,67 \\
\hline Eğitim durumu & & \\
Lise & 46 & 16,03 \\
Önlisans & 99 & 34,50 \\
Lisans & 127 & 44,25 \\
Lisansüstü & 15 & 5,22 \\
\hline Departman & & \\
Önbüro & 65 & 22,65 \\
Idari işler & 44 & 15,33 \\
Muhasebe & 18 & 6,27 \\
Yiyecek-içecek & 57 & 19,86 \\
Servis & 65 & 22,65 \\
Mutfak & 38 & 13,24 \\
\hline Toplam & 287 & 100,00 \\
\hline
\end{tabular}

Tablo 1 incelendiğinde katılımcıların yarıdan fazlasının kadın, büyük oranda 26-30 yaş grubunda ve lisans mezunu olduğu görülmektedir.

Uyarlama ve Çeviri Çalışması: İngilizce olarak geliştirilen ölçeğin Türkçeye uyarlama ve çevirisi için bir dizi çalışma gerçekleştirilmiştir. Öncelikle araştırmacıların da içinde bulunduğu konusunda uzman doktora eğitim seviyesine sahip 9 akademisyen tarafından ölçeğin Türkçeye çevirisi yapılmıştır. Çeviriden kaynakı oluşabilecek anlam kaymalarını ortadan kaldırmak için geri çevirme yöntemiyle tekrar İngilizceye çevrilmiştir. Geri çevirme işlemi bağımsız üç çevirmen tarafından yapılmıştır. Geri çevirme işlemi sonucunda oluşturulan Türkçe form iki dil uzmanı tarafından incelenmiş ve ölçekte uzman görüşü alınarak bazı değişiklikler yapılmıştır. Türkçeye uyarlanan ve çevirisi yapılan ölçek 50 kişilik bir pilot gruba uygulanarak anlaşılmayan veya tereddüt yaşanan sorular tespit edilmiş ve yeniden düzenlenerek aynı gruba tekrardan uygulanmıştır. 
Anlaşılmayan ya da tereddüt yaşanan soruların düzenlenmesiyle zorunlu vatandaşılı davranışı ölçeğinin Türkçeye uyarlama ve çeviri işlemi tamamlanmıştır.

\section{Bulgular}

\subsection{Geçerlilik Çalışmaları}

Türkçeye uyarlama ve çeviri işlemi tamamlanan ölçeğinin geçerliliğini tespit edebilmek maksadıyla; dilsel geçerlilik, ıraksak geçerlilik ve ölçeğin yapı geçerliği test edilmiştir.

Dilsel Eşdeğerlik: Ölçeğin orijinal İngilizce hali ile Türkçeye uyarlanmış ve çevrilmiş formu arasında tutarııı̆ı tespit etmek maksadıyla dilsel eşdeğerlilik çalışması yapılmıştır (Hambleton ve Bollwark, 1991). Bu kapsamda araştırmanın yapılacağı otellerde İngilizce ve Türkçe dillerine ileri seviyede hâkim olan 55 çalışan tespit edilmiş ve bu çalışanlara önce ölçeğin orijinal İngilizce formu, iki gün sonra ise ölçeğin Türkçe formu uygulanmıştır. Katılımcıların ölçekte yer alan sorulara verdikleri puanların tutarlığı Pearson momentler çarpım korelasyon katsayısı incelenerek test edilmiştir. Elde edilen sonuçlar Tablo 2' de sunulmuştur.

Tablo 2. Ölçek Maddelerinin İngilizce ve Türkçe Çevirileri Arasındaki Korelasyonlar

\begin{tabular}{|c|l|c|c|c|c|}
\hline Maddeler & Uygulama & $\mathbf{N}$ & $\mathbf{X}$ & Ss & $\boldsymbol{R}$ \\
\hline \multirow{2}{*}{ ZVD1 } & Türkçe & 55 & 3,55 & 1,16 & \multirow{2}{*}{$0,859^{* *}$} \\
\cline { 2 - 5 } & İngilizce & 55 & 3,41 & 1,32 & \\
\hline \multirow{2}{*}{ ZVD2 } & Türkçe & 55 & 3,55 & 1,03 & \multirow{2}{*}{$0,894^{* *}$} \\
\cline { 2 - 5 } & İngilizce & 55 & 3,61 & 0,99 & \\
\hline \multirow{2}{*}{ ZVD3 } & Türkçe & 55 & 3,71 & 0,99 & \multirow{2}{*}{$0,885^{* *}$} \\
\cline { 2 - 5 } & İngilizce & 55 & 3,50 & 0,87 & \\
\hline \multirow{2}{*}{ ZVD4 } & Türkçe & 55 & 3,68 & 1,02 & \multirow{2}{*}{$0,904^{* *}$} \\
\cline { 2 - 5 } & İngilizce & 55 & 3,77 & 0,91 & \\
\hline \multirow{2}{*}{ ZVD5 } & Türkçe & 55 & 3,60 & 1,05 & \multirow{2}{*}{$0,875^{* *}$} \\
\cline { 2 - 5 } & İngilizce & 55 & 3,66 & 1,16 & \\
\hline \multirow{2}{*}{ Genel } & Türkçe & 55 & 3,61 & 0,87 & \multirow{2}{*}{$0,895^{* *}$} \\
\cline { 2 - 5 } & İngilizce & 55 & 3,40 & 0,96 & \\
\hline
\end{tabular}

$\mathrm{N}=55,{ }^{*} \mathrm{p}<0,05$

Tablo 2 incelendiğinde ölçeğin orijinal İngilizce formu ile Türkçe formu arasında yüksek düzeyde anlamlı ve pozitif yönlü bir ilişki olduğunu görülmektedir $(r=0,895, p<0,05)$. Ölçeğin İngilizce ve Türkçe formları arasındaki bu yüksek korelasyon, çevirinin dilsel eşdeğerliğinin sağlandığını göstermektedir.

Yakınsak Geçerlilik (Benzeşim Geçerliliği): Yakınsak geçerlilik sağlanabilmesi için "Ortalama Açıklanan Varyans (AVE)" değerinin 0,5'den büyük olması ve Birleşik Güvenirlik (CR) değerinin, Ortalama Açıklanan Varyans (AVE) değerinden büyük olması gerekmektedir (Hair vd., 2006). Zorunlu vatandaşlık davranışı ölçeğinin yakınsak geçerliliğinin test edilebilmesi için "Ortalama Açıklanan Varyans (AVE)" değeri 0,605, Birleşik Güvenirlik (CR) değeri 0,884 olarak hesaplanmıştır. Elde edilen değerler incelendiğinde, uyarlama ve çevirisi yapılan zorunlu vatandaşlık davranışı ölçeğinin yakınsak geçerliliği sağladığı görülmektedir. Bu durum ölçekte yer alan maddelerin birbirleri ile ve oluşturdukları faktörle ilişkili olduğunu göstermektedir.

Yapı Geçerliği: Uyarlama ve çevirisi yapılan zorunlu vatandaşlık davranışı ölçeğinin yapı geçerliliğinin test edilebilmesi maksadıyla keşfedici faktör analizi (KFA) ve doğrulayıcı faktör analizi (DFA) yapılmıştır. Keşfedici faktör analizi, ilgili ölçekte bulunan gizil değişkenlerin hangi faktörler altında toplandığını tespit etmek amacıyla, doğrulayıcı faktör analizi ise daha önceden geliştirilen, geçerlilik ve güvenirliliği test edilerek uygulanan ölçeğin Türkiye'deki örneklem grubu için uygunluğunu test etmek amacıyla yapılmıştır.

Keşfedici Faktör Analizi (KFA): Uyarlama ve çevirisi yapılan zorunlu vatandaşlık davranışı ölçeğinin yapısal geçerliliğini tespit etmek maksadıyla Temel Bileşenler Analizi ve Varimaks Eksen Döndürmesi Tekniği 
kullanılarak KFA uygulanmıştır. Keşfedici faktör analizinin yapılabilmesi için gerekli örneklem büyüklügünün belirlenmesi konusunda literatürde genel kabul görmüş bir görüş birliği bulunmamaktadır. Kline (2014) örneklem büyüklüğünün ölçekteki soru sayısının 10 katı olması gerektiğini belirtirken, Bryman ve Cramer (2002) ölçekteki soru sayısının 5 katının yeterli bir örneklem büyüklüğü olduğunu, Gürbüz ve Şahin (2014) ise sosyal bilimlerde 200-250 arasındaki bir örneklem büyüklüğünün yeterli olabileceğini belirtmektedirler. Yapılan keşfedici faktör analizi neticesinde, Kaiser-Meyer-Olkin (KMO) örneklem yeterlilik değerinin 0,870 olduğu ve örneklemin büyüklüğünün faktör analizi için yeterli olduğu bulgusuna ulaşılmıştır ( $N=287$ ). Bartlett küresellik testinin anlamlı olması $\left(\chi^{2}(10)=769,378, p<0,05\right)$ değişkenler arasındaki kolerasyon ilişkilerinin faktör analizi için uygun olduğuna işaret etmektedir. KFA analizinde özdeğerlerin 1'den büyük olması durumunda faktörlerin oluşması sağlanmıştır. KFA analizi neticesinde, tek faktörlü bir sonuç elde edilmiştir. Yamaç serpinti grafiği ve faktörlerin açıkladıkları varyanslar dikkate alınarak tek faktörlü yapının uygun olacağı görülmüştür. Bu doğrultuda beş gizil değişkene sahip zorunlu vatandaşılı ölçeğinin tek faktörlü bir yapıda olduğu, toplam varyansın $\% 60,58$ 'ini açıkladığı ve maddelerin faktör yüklerinin 0,734 ve üzerinde olduğu tespit edilmiştir. Uyarlama ve çevirisi yapılan zorunlu vatandaşlık ölçeğinin KFA sonuçları Tablo 3'de yamaç serpinti grafiği ise Şekil 1'de gösterilmiştir.

\section{Şekil 1. Yamaç Serpinti Grafiği}

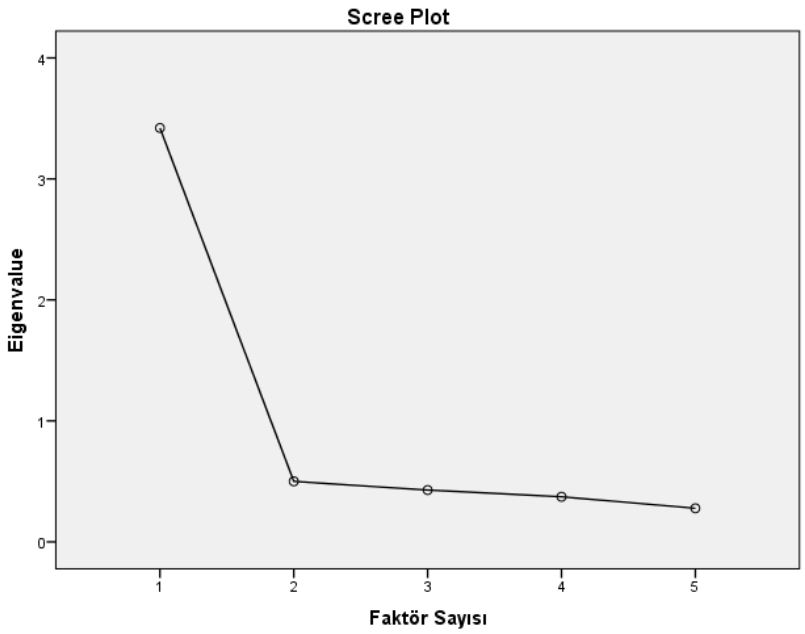

Tablo 3. Yaşam Doyumu Ölçeğine Illişkin Keşfedici Faktör Analizi Sonuçları

\begin{tabular}{|c|c|}
\hline & Faktör Yükleri \\
\hline $\begin{array}{l}\text { Çalıştığım yerdeki yöneticiler, çalışanlarına resmi görevlerinin dışında ekstra faaliyetlerde bulunmaları için baskı } \\
\text { uygular. }\end{array}$ & 0,799 \\
\hline $\begin{array}{l}\text { Çalıştığım yerde herhangi bir resmi ödül olmadan, normal çalışmam gereken sürelerin dışında ekstra sürelerde } \\
\text { çalışmak için sosyal bir baskı vardır. }\end{array}$ & 0,847 \\
\hline Görevimi yaparken, resmi işlerimin dışında ekstra çaba harcamam için bir beklenti olduğunu hissediyorum. & 0,747 \\
\hline $\begin{array}{l}\text { Yeterli zamanım ya da enerjim olmadığında bile, kendi işlerimin dışında benden diğer çalışanların işlerine de } \\
\text { yardımcı olmam konusunda bir baskı olduğunu hissediyorum. }\end{array}$ & 0,759 \\
\hline $\begin{array}{l}\text { İsteğim olmamasına karşın, normal yapmam gereken işlerin dışında, amirime yardım etmem konusunda } \\
\text { üzerimde bir baskı olduğunu hissediyorum. }\end{array}$ & 0,734 \\
\hline Toplam Varyans & $\% 60,579$ \\
\hline KMO & 0,870 \\
\hline
\end{tabular}


Doğrulayıcı Faktör Analizi (DFA): Uyarlama ve çevirisi yapılan zorunlu vatandaşlık davranışı ölçeğinin yapı geçerliliğini test etmek için AMOS 18 paket programı kullanılarak doğrulayıcı faktör analizi (DFA) yapılmıştır. Testte, kovaryans matrisinin maksimum olasılık tahmini kullanılmıştır. Ölçeğin yapısal geçerliliğini test etmek için yapılan doğrulayıcı faktör analiz diyagramı Şekil 2'de, sonuçları ise Tablo 4'de sunulmuştur.

Şekil 2. Doğrulayıcı Faktör Analiz Diyagramı

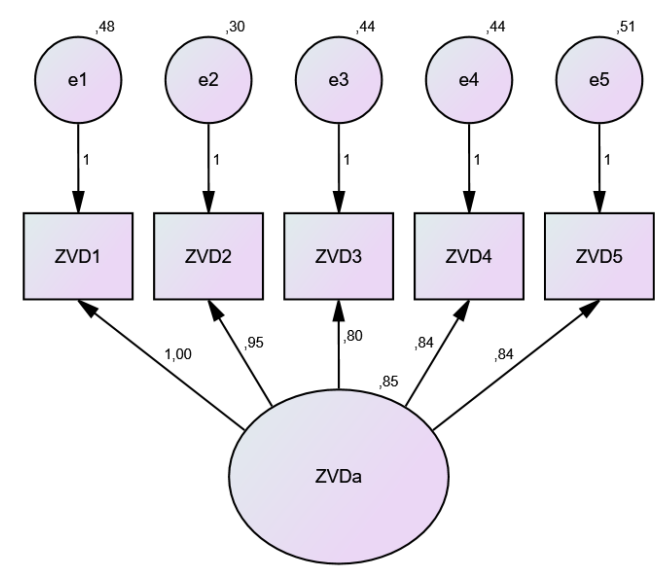

Tablo 4. Zorunlu Vatandaşlık Davranışı Ölçeğinin Yapısal Geçerliliğine Yönelik Uyum İyiliği Değerleri

\begin{tabular}{lc}
\hline Uyum Iyiliği indeksleri & Değer \\
\hline$\chi^{2} / s d$ & 3,240 \\
NFI & 0,989 \\
IFI & 0,955 \\
CFI & 0,978 \\
RMSEA & 0,075 \\
GFI & 0,986 \\
\hline
\end{tabular}

Şekil 2'de görüldüğü üzere zorunlu vatandaşlık davranışı ölçeğinin orijinal halinde herhangi bir modifikasyona ihtiyaç duyulmamıştır. Tablo 4 incelendiğinde tek faktörlü bir yapıya sahip olan zorunlu vatandaşlık davranışı ölçeğinin genel uyum değerini gösteren Ki-kare/serbestlik derecesi [CMIN/DF]=3,240 kabul edilebilir değerler içinde olduğu görülmektedir. Bununla beraber karşılaştırmalı uyum indekslerinden; Normlaştırılmış Uyum İndeksi (NFI) $=0,989$, Artırmalı Uyum İndeksi (IFI) $=0,955$, Karşılaştırmalı Uyum İndeksi $(\mathrm{CFI})=0,978$ ve Yaklaşık Hataların Ortalama Karekökü Değeri (RMSEA) $=0,075$ olarak hesaplanmıştır. Bu değerler ölçeğin karşılaştırmalı uyum indekslerinin kabul edilebilir bir uyuma sahip olduğunu göstermektedir (Meydan ve Şeşen, 2011). Iyilik uyum indeksinin (GFI=0,986) 0,90 üzerinde olması ise ölçeğin iyi uyum gösterdiğinin bir ölçütüdür (Harrington, 2009).

\subsection{Güvenirlik Çalışmaları}

Türkçeye uyarlama ve çeviri çalışması yapılan zorunlu vatandaşık davranışının güvenirliğinin test edilmesi maksadıyla Fornell ve Larcker'ın (1981) bileşik güvenirlik testi ve Cronbach'ın (1951) iç tutarlılık testinden faydalanılmıştır. Yapılan testlerde ölçeğin bileşik güvenirlik değeri (CR) 0,884 , iç tutarlılı̆ını gösteren Cronbach alfa güvenilir değeri ise 0,885 olarak hesaplanmıştır. Elde edilen değerlerin 0,7 'nin üzerinde olması, Türkçeye uyarlanan ve çeviri çalışması yapılan zorunlu vatandaşık davranışı ölçeğinin güvenilir ve iç tutarlılığının olduğunu göstermektedir (Hair vd., 2006).

Test Yeniden Test: Ölçeğin zamana karşı tutarlı ölçümlere sahip olup olmadığını tespiti maksadıyla test yeninden test tekniğinden yararlanılmıştır. Bu maksatla 50 otel çalışanı örneklem olarak belirlenmiş ve 20 gün ara ile hazırlanan anket otel çalışanlarına uygulanmıştır. İki uygulama arasındaki korelasyon katsayısı $(r=0,891, p<0,05)$ olması ölçeğin zamana göre değişmez olduğunu göstermektedir. 


\section{Sonuç ve Tartışma}

Bu araştırmada Vigado-Gadot (2007) tarafından geliştirilen zorunlu vatandaşık davranışı ölçeğinin Türkçeye uyarlanması ve çevirisi amaçlanmıştır. Sosyal bilimlerde yapılan araştırmalarda kullanılan ölçüm araçları bölgesel ve kültürel farklılıklardan etkilenmektedir. Bu nedenle ölçeğin orijinal hali ve araştırmanın yapıldığı ülkeler arasındaki kültürel farklııklar araştırma sonuçlarında tutarsızlığa sebep olurken, araştırmanın da geçerliliğini tehdit edebilmektedir. Bu nedenle farklı dilde geliştirilen ve uygulanan ölçeklerin araştırmanın yapıldığı dile ve uygulanacağı kültüre göre uyarlanması araştırmanın geçerliliğini ve güvenirliliğini artırmak için zorunludur. Bu bakış açısından yola çıkarak araştırmada önce orijinal formu İngilizce olan ölçeğin çeviri çalışması yapılmış ve örneklem gruba uygulanarak anlaşılmayan veya tereddüt yaşanan maddeler yeniden düzenlenmiştir. Yeniden düzenlenen ölçeğin orijinal formu ve Türkçe formları İngilizce ve Türkçeye hakim 55 kişilik aynı örneklem gurubuna uygulanarak veriler incelenmiş ve katılımcıların her iki formda yer alan sorulara verdikleri puanların tutarlığı Pearson momentler çarpım korelasyon katsayısı incelenmiştir. Orijinal İngilizce formu ile Türkçe formu arasında yüksek düzeyde anlamlı ve pozitif yönlü bir ilişkinin olması $(r=0,895, p<0,05)$ ölçeğin dilsel eşdeğerliliğinin sağlandığını göstermektedir. Dilsel eşdeğerliliğinin tespit edilmesinden sonra ölçeğin yakınsak geçerliliğinin (benzeşim geçerliliği) tespit edilebilmesi maksadıyla "Ortalama Açıklanan Varyans (AVE=0,605) değeri ve Birleşik Güvenirlik $(C R=0,884)$ değerleri hesaplanmıştır. Elde edilen değerler, ölçeğin yakınsak geçerliliğinin olduğunu göstermiştir. Geçerlilik çalışmasının son aşamasında ise ölçeğinin yapı geçerliliği test edilmiştir. Bu maksatla keşfedici faktör analizi (KFA) ve doğrulayıcı faktör analizleri (DFA) yapılmıştır. Yapılan keşfedici faktör analizinde beş gizil değişkene sahip zorunlu vatandaşlık ölçeğinin tek faktörlü bir yapıda olduğu, toplam varyansın \%60,58 açıkladığı ve maddelerin faktör yüklerinin 0,734 ve üzerinde olduğu tespit edilmiştir. Doğrulayıcı faktör analizi AMOS 18 paket programı ile yapılmıs ve ölçeğin orijinal halinde herhangi bir modifikasyon yapılmadan yeterli uyum değerlerine sahip olduğu tespit edilmiştir.

Çalışmanın son aşamasında ise ölçeğin güvenilirliği test edilmiştir. Bileşik güvenirlik test değeri 0,884 ve iç tutarlıı̆̆ını gösteren Cronbach alfa değeri ise 0,885 olarak hesaplanmıştır. Elde edilen değerler doğrultusunda ölçeğin güvenilir olduğu tespit edilmiştir. Ölçeğin zamana karşı tutarlı ölçümlere sahip olup olmadığını tespiti maksadıyla yapılan "test yeninden test tekniği" $(r=0,891, p<0,05)$ sonuçları ölçeğin zamana göre değişmez olduğunu göstermektedir.

Yapılan analizler neticesinde ölçeğin Türkçe formunun geçerli ve güvenilir bir ölçme aracı olduğu ve Türkiye'deki örneklem gruplarına uygulanabileceği tespit edilmiştir. Zorunlu vatandaşlık davranışı ölçeğinin Türkçeye uyarlanması 2017 yılında yapılmış olsa da, yapılan çalışmada ölçeğin aslına sadık kalınmayarak, sektörel uyarlama yapılmış ve ölçeğe ait ifadeler hastanede çalışan hemşirelere yönelik olarak düzenlenmiştir. Bu uyarlama işlemi ölçeğin üretim ve diğer hizmet sektörlerine yönelik çalışmalarda kullanılmasına kısıtlama getirmektedir. Araştırmamız kısıtlamayı ortadan kaldırarak, zorunlu vatandaşlık davranışı ölçeğinin tüm sektörlere yönelik kullanılabilirliği sağlamaktadır.

Örgüt içerisindeki çalışanların zorunlu vatandaşlık algılarını tespit etmeye yönelik yapılacak araştırmalarda kullanılabilir olan bu ölçme aracının Türkiye'de yapılacak araştırmalara katkı sağlayacağı ve uygulayıcıların bu konudaki farkındalıklarının artmasına katkı sağlayacağı değerlendirilmektedir.

\section{Beyan ve Açıklamalar (Disclosure Statements)}

1. Bu çalışmanın yazarları, araştırma ve yayın etiği ilkelerine uyduklarını kabul etmektedirler (The authors of this article are admitted that they complied with the principles of research and publication ethics).

2. Yazarlar tarafından herhangi bir çıkar çatışması beyan edilmemiştir (No potential conflict of interest was reported by the authors).

3. Bu çalışma, intihal tarama programı kullanılarak intihal taramasından geçirilmiştir (This article was screened for potential plagiarism using a plagiarism screening program). 


\section{Kaynaklar}

Akinlotu, O., \& Ertan, Ş. S. (2018) An assesment of perceived stress sources among university students: European University of Lefke context. LAÜ Sosyal Bilimler Dergisi, 9(1), 35-48.

Bryman, A., \& Cramer, D. (2002). Quantitative data analysis with SPSS release 10 for Windows: A guide for social scientists. Routledge.

Cronbach, L. J. (1951). Coefficient alpha and the internal structure of test. Psychometrika, 16(3), 297-334.

Fornell, C., \& Larcker, D. F. (1981). Evaluating structural equation models with unobservable variables and measurement error. Journal of Marketing Research, 18(1), 39-50.

Gürbüz, S., \& Şahin, F. (2014). Sosyal bilimlerde araştırma yöntemleri. Ankara: Seçkin Yayıncılık.

Hair, J. F., Black, W. C., Babin, B. J., Anderson, R. E., \& Tatham, R. L. (2006). Multivariate data analysis (6. baskı).

Hambleton, R. K., \& Bollwark, J. (1991). Adapting tests for use in different cultures: Technical issues and methods. U.S. Department of Education, 1-44.

Harrington, D. (2009). Confirmatory factor analysis. Oxford University Press.

Ke, W., \& Wei, K. K. (2008). Organizational culture and leadership in ERP implementation. Decision Support Systems, 45(2), 208-218.

Kline, P. (2014). An easy guide to factor analysis. Routledge.

Meydan, C. H., \& Şeşen, H. (2011). Yapısal eşitlik modellemesi AMOS uygulamaları. Detay Yayıncılık.

Organ, D. W. (1997). Organizational citizenship behavior: It's construct clean-up time. Human Performance, 10(2), 8597.

Organ, P., Philip, M., Podsakoff, P. M., \& Mackenzie, S. B. (2006). Organizational citizenship behavior: Its nature, antecedents, and consequences. Sage, Thousand Oaks, 16, 43-44.

Peng, Z. L., \& Zhao, H. D. (2012). Does organization citizenship behavior really benefit the organization? Study on the compulsory citizenship behavior in China. Nankai Business Review International, 3(1), 75-92.

Podsakoff, P. M., Ahearne, M., \& MacKenzie, S. B. (1997). Organizational citizenship behavior and the quantity and quality of work group performance. Journal of Applied Psychology, 82(2), 262.

Smith, C. A., Organ, D. W., \& Near, J. P. (1983). Organizational citizenship behavior: Its nature and antecedents. Journal of Applied Psychology, 68(4), 653.

Vigoda-Gadot, E. (2006). Compulsory citizenship behavior: Theorizing some dark sides of the good soldier syndrome in organizations. Journal for the Theory of Social Behaviour, 36(1), 77-93.

Vigoda-Gadot, E. (2007). Leadership style, organizational politics, and employees' performance: An empirical examination of two competing models. Personnel Review, 36(5), 661-683.

Yen, H. R., \& Niehoff, B. P. (2004). Organizational citizenship behaviors and organizational effectiveness: Examining relationships in Taiwanese banks. Journal of Applied Social Psychology, 34(8), 1617-1637.

Zhao, H., Peng, Z., Han, Y., Sheard, G., \& Hudson, A. (2013). Psychological mechanism linking abusive supervision and compulsory citizenship behavior: A moderated mediation study. The Journal of Psychology, 147(2), 177-195 
This Page Intentionally Left Blank 